\title{
Sources and Uses of Fuel for Fish Smoking Around the Lake Chad in Borno State, Nigeria
}

\author{
Yerima, I. \& Y. M. Ngulde \\ Department of Biological Sciences, Faculty of Science, University of Maiduguri, \\ Nigeria \\ E-mail: yerima.ibrahim@yahoo.com
}

Received: Sep. 5, 2015 Accepted: Sep. 13, 2015 Published: December 11, 2015

doi:10.5296/jee.v6i2.8707 URL: http://dx.doi.org/10.5296/jee.v6i2.8707

\begin{abstract}
Fuel around the rural fishing community of the Lake Chad in Borno state is scarce and expensive. Where it is available it is at a distance of $120 \mathrm{~km}$ therefore alternative and strategy must be developed to provide fuel to the fishing community to preserve the large volume of fish landed around the Lake Chad. A visit was made to the lake shores to identify the various types of materials in use by the processors as fuel and analysis of the fuel types were made, especially moisture content being the most important factor in determining the energy value of a fuel. The fuel types were compared to the type and quantity of fish landed daily. The analysis of variance between paired fuel types was found to be significant at $1 \%$ with low coefficient of variation. In this study Eucalyptus camaldulenis and Acacia senegal were found to have the least moisture content and available to processors. Rice hull which has a $0.001 \%$ surface moisture content was not known to the processors as biofuel. Which we hope to introduced at the end of the research. The use of cowdung was always minimized due to its social ills.
\end{abstract}

Keywords: Fish, Lake chad, Fuelwood, Smoking klin, Shelf life 


\section{Introduction}

The rural fishing industry around the Lake Chad involves among other things, supplying of fish to the Nigerian markets. The smoking of fish which accounts for a large proportion of the fish sent to Nigerian markets from the Baga fisheries of Lake Chad within the Chad Basin, consumes large quantity of fuelwood, although it has not been responsible for deforestation around Baga (Neiland and Verinumbe, 1990b), but possibly around Marte and Kiranawa, a distance of about 1 Baga (Lake Chad) fishing industry. The fuelwood which has been the t00km from Baga (Lake Chad Shores) which has been the major sources of fuelwood for the raditional source of fuel around the Lake is scarce and expensive, primarily due to deforestation, overgrazing, transportation to island, lack of cold chain to preserve fresh fish, demand for fuelwood for other domestic uses and improper drying of wood. These problems are compounded by increasing human population, lack of electricity, cost of petroleum energy, lack of enforcement of forestry laws in the country. These problems therefore put a lot of pressure on the only means and accessible traditional sources of fuel, to local fishing community around the Lake Chad.

The volume of fish of different species and sizes landed from the Lake Chad fishing industry undergo spoilage from rottening due to infestation by the insect Dermestes beetles in the course of storage before transportation to various markets in the southern part of Nigeria.

Azeze (1979a and 1979b) indentified the insect Dermestes beetle and poor method of processing as responsible for fish rottening and protein losses.

Similarly Azeza (1982) observed that the processed fish sent to southern markets of Nigeria are variable in quality with significant losses associated with insect infestation, internal rottening due to inadequate drying of the products. Azeza (1983) indicated that pesticides residues are not present in Lake Chad fish production against insects infestation. The major technological approaches to reducing the post harvest losses includes drying, smoking, brining, salting, improved packaging and better hygiene. Davis and Davis (2009), observed a similar method in the coastal region of Nigeria with $36 \%$ brining $26 \%$ brine-Smoking and smoke-sun drying as most prominent method of fishing processing. Eyo (1980) similarly observed the effect of Smoke component. The technological approach requires an extra effort to accommodate the volume of fish landed annually. Azeza (1986) observed that between 1963 to 1971 total catch rose from 20, 000 t/annum to over 100000 tones due to an increase in total effort and the on the quantity and shelf life of fish development of strong trade in fish product in Nigeria.

Durand (1980) based on round traffic census of processed fish between 1962 and 1970 total catch rose from 40,000 to 80,000 tones, while between 1971 to 1974 the yearly catches rose even faster reaching, a maximum of 220,000 tons in 1974 corresponding to a period of severe Sahel drought. Post 1975 total catch has remaind at about 100,000 t/annum, a level sustainable by the small rate of the Lake Chad measuring $8-10,000 \mathrm{~km}^{2}$.

Hopson (1967a, 1967b, 1968 and 1972b) worked on the checklist of species, method of fishing and processing, population studies, fishing practice and biology $(1965,1967 \mathrm{c}$ and 
1972b) generally he studied the biology of the Lake Chad fisheries investigating water, temperature, life cycle, hydrological cycle, and habitat species, part content and morphology of the different species respectively especially the fish types of niloticus and the management system as observed by Marie-Therese (1984). The foregoing therefore indicates that the fisheries of the Lake Chad have been the subject of detailed research and are probably as well known as many other inland fisheries in Africa. Neiland and Verinumbe (1990a) observed that a number of fisheries development projects have taken place in the past in the region concentrating on the introduction of new gear and improved fish processing methods. Hopson (1968), Observed the type of gillnet used in the fisheries of the Lake Chad.

However, the major problem within the basin is how to preserve the large volume of fish landed to withstand shelf life and transportation. This became difficult to achieve due to the large volume of fish landed as indicated by (Neiland and Verinumbe, 1990a), and the (United Nation, 1977) that the Lake the Lake Chad annual fish landing of 100000 and 1.7 million tons/annum respectively. However, they cited fuelwood to be the major sources of energy used in smoking the fish in the area. In the same vein it was observed that fisheries of the Lake Chad are among the most productive in the whole continent, as a result, this resources has a high economic and nutritional significance to the region (FAO 1975) and to many distant urban fish markets in Nigeria. (Neiland and Verinumbe (19190a), indicated that, lack of adequate energy around the area has been responsible for large spoilage of fish sent to most Nigerian markets. Neiland and Verinumbe (1990a), indicated that one tone of Banda (smoke Clarias tied head to tail) in Maiduguri is equivalent to five tones of fresh fish from the lake. This research therefore looks into the most economical source of fuel and appropriate method of processing the large volume of fish landed in the area. Consider five tones of fresh fish if processed, the weight is reduced to one tone of the Clarias tied head to tail as indicated (Neiland and Verinumbe 1990a). Therefore combustible materials ,plants and wastes products as fuel locally available and acceptable with the appropriate devices could be assessed for improvement and recommendation to the people. This research will therefore investigate the technique of fish smoking with particular type of fuel and its economic consumption and secondly investigate the type of kiln used in smoking the fish.

\section{Materials and Method}

\subsection{Field Observation}

The study was carried out around the Lake shores of the Lake Chad in the year 1995 in two stages, comprising field and Laboratory. The first was a visit to fish processing locations around the lake shores to administer questionnaire and make personnel contact and observation with fishermen and fish processors. While the questionnaire was administered and samples of fuel types were investigated .About nine tree species and two waste materials, namely Zizyphus spina Christi, Gmelina arborea,Cassina siamea, Accasia senegal, Eucalyptus camaldulensis, Calotropis procera, Azadirachta indica, Acacia nilotica, Acacia Senegal along with Rice hull (husk) and Cow dung as available waste material for assessement as fuel were randomly assessed for quantity and use as fuel. Collection was based purely on availability, usage and preference by fish processors, per location. 
Fish processors were randomly administered questionnaires to determine the type of fuel used and why, cost of fuel, availability, preference, quantity used per unit volume of fish and method of utilization in different smoking kiln, personnel observation and communication were also made some fuel types which the farmers or the processors want to be kept confidential because of the socio-economic ill and attached stigma. One of such fuel is the use of cow dung in smoking fish.

\subsection{Laboratory Procedure}

The laboratory method involves determination of the energy value of different types of plant species and waste material, used by the processors. Measurements of fuel value of the materials were based on several attributes as recommended by (National Academy of science 1980). Of the eleven fuel types only nine were assessed either as imported from Marte and kiranawa (a (distance of $120 \mathrm{~km}$ away from Lake shores) or locally collected. Among the seven assessed, Colotropis and cow dung were collected locally while, Acacia nilotica, Accacia senegal and Zizyphus spina, christi, Acacia senegal were abundant. Rice hull was also available in rice processing areas, called Abadam, some distance away from the fish processing centers. All the seven fuel types were screened for the following measurement, moisture content, caloric value, ash content, density, charcoal quality, net energy and the type of kiln used as were described subsequently.

Measurement was also taken for the quantity of fuel used per unit volume of fish. In this case samples of fish from the eleven locations visited were taken to the laboratory for the determination of total weight, number, average weight (wet) and dry weight. Percentage proportion loss in weight due to dressing percentage loss in weight due to smoking to dry in each of the eleven locations.

\subsection{Smoking Devices}

The types of smoking kilns were also assessed for performance. There were three types of smoking kilns used by the processors assessed and measured for volume. The rectangular types were measured for length, width and height, the dome shaped type was measured for diameter and height as adopted by (Hau and M. Allau, 1993). While the pit type was measured for width and length, materials used in the construction were also examined and recorded.

The seven different types of plants and wastes materials used as fuel were subjected to analysis of variance and coefficient of variation, measurement of the seven plants species and two wastes materials for the various attributes were carried out as follows.

\subsection{Moisture Content}

The moisture content was determined by measuring an initial quantity of $1000 \mathrm{gms}$ wood rice hull air dried to constant weight using the Harris weighing balance. The piece of wood or the loose rice hull and cow dung were dried in the open air using a metal tray, but a perforated metal plate was used in covering the rice hull to ensure that some quantity was not lost to blowing wind. This was done to prevent lost of weight due to blown off quantity . The solid 
wood or cow dung was also placed on the same type of tray to dry out. Loss in weight was measured after the third day of drying and repeated after the sixth day for the rice hull. While the solid wood were recorded for loss of weight after seven days where a constant weight was recorded.

The percentage of moisture in a wood can be presented in two ways (NAS 1980) Using the formula, based on wet weight basis $=\frac{\text { Wet Weight Dry weight }}{\text { Wet weight }}$

$$
\text { Dry weight based }=\frac{\text { Wet }- \text { weight }- \text { Dry weight }}{\text { Dry weight }}
$$

(Porteous, 1978 indicated that all moisture content are of wet weight basis e.g. green wood has a moisture content ranging from $25-60 \%$.

\subsection{Ash Content}

1000grams $(1 \mathrm{~kg})$ of rice hulls or solid wool was measured or weight using the Harris weighting balances. The rice hull or piece of wool was burnt on a metal plate to ensure that no quantity of the ash was lost after burning. During the burning process the samples were mixed (at an interval of 10minutes) to ensure complete consumption. The samples took approximately four hours to burn completely to ashes for the rice hull and for the other solid wood; it took varying periods all time within a period at two hours.

Thus ash material referred dry caloric value determined were recorded for ash content and weighted for percentage ash caloric.

$$
\% \text { ash was calculated }=\frac{(\text { weight ash caloric }+ \text { ash })-\text { weight }(\mathrm{per} / \mathrm{v} 100)}{\text { Weight of }}
$$

National Academy of science,(1980) indicated out in a wood test per ash.

\subsection{Densities}

The Density of a material is the mass per unit volume. $100 \mathrm{ml}$ of rice hull and $1 \mathrm{~kg}$ of wood was measured for density. The mass of both the rice hull and wood was determined using an electronic weighting balance. The density of the rice hull and wood were therefore determined by density and their mass by volume occupied i.e. Density $(\ell)=$ mass/volume.

\subsection{Air pockets or Compaction (pores)}

An electronic weighting machine was used to measure $1 \mathrm{~kg}$ of rice hull and the air pockets were counted manually. While a kilogram of wood was observed for pores and as a sign of compaction of wood. This procedure was repeated and an average of the values was taken and recorded.

The caloric value of rice hull was determined using percentage value of ash content and 


\section{Macrothink}

moisture content. The gross (or higher) caloric value (HCV) was calculated thus:

$$
\mathrm{HCV}=20.0 \times(1-\mathrm{A}-\mathrm{M}) \mathrm{mjkg}-1
$$

Where

$$
\begin{gathered}
\mathrm{A}=\% \text { ash content } \\
\mathrm{M}=\% \text { moisture content }
\end{gathered}
$$

The net (or lower ) caloric value (LCV) which takes into account conserved energy from the water vapour from inherent moisture and from the oxidation of the hydrogen content is sometimes used. The LCV was therefore calculated as:

$$
\mathrm{LCV}=18.7 \times(1-\mathrm{A}-\mathrm{M})-2.5 \times \mathrm{M} \mathrm{Mjkg}-1
$$

\section{Result and Discussion}

In this research the different types of fuel materials identified around the Lake-chad includes plant species such as Zizyphus spina ,Christi, Gmelina arborea, Cassia Siamea, Accasia Senegal, Eucalyptus camaldulensis, Calotropis, mocera, Azadrichta indica, Acasia milotica and waste material, like rice hulk and cowdung. Out of the eleven fuel types identified only five of them were commonly in used by the fish processor, namely Acacia nilotica, Acacia fadherbie, Azadirachta indica, calotropis procera and cowdung. The remaining six types were at a distance away from the fish processors, these includes plants like Zizygphus, spine Christi, Gmelina arborea, Casia siamea, Acasia seyal, Eucalyptus camaldulensis, Accia senegal and rice hull.

The energy potentials of both fuel material in use and those at a distance and not accessible were found to have the following varying economic values in smoking, preserving and processing fish as shown in table 1.

Table 1. Showing the various attributes of biofuel materials

\begin{tabular}{|l|l|l|l|l|l|l|}
\hline Fuel types & $\begin{array}{l}\text { Moisture } \\
\text { content \% }\end{array}$ & $\begin{array}{l}\text { Caloric } \\
\text { value } \\
\text { kca }\end{array}$ & Densities & $\begin{array}{l}\text { Specific heat } \\
\text { capacity } \\
\text { j/kg }\end{array}$ & $\begin{array}{l}\text { Specific } \\
\text { gravity }\end{array}$ & $\begin{array}{l}\text { Volume } \\
\text { L }\end{array}$ \\
\hline $\begin{array}{l}\text { Zizyphus } \\
\text { spine } \\
\text { chromea }\end{array}$ & 58.4 & 3076.6 & dense & 1011.0 & 0.93 & 21.01 \\
\hline $\begin{array}{l}\text { Gmehira } \\
\text { arborea }\end{array}$ & 47.23 & 4741.31 & dense & 2304.0 & $0.42-0.61$ & 22.7 \\
\hline $\begin{array}{l}\text { Cassia } \\
\text { siameases }\end{array}$ & 45.23 & 5883.72 & dense & 1122.0 & $0.6-0.8$ & 15.3 \\
\hline $\begin{array}{l}\text { Accasia } \\
\text { senegal }\end{array}$ & 42.6 & 4666.1 & dense & 1133.0 & 1 & 13.3 \\
\hline $\begin{array}{l}\text { Eucalyptus } \\
\text { lamalulemen }\end{array}$ & 38.6 & 5506.92 & dense & 336.0 & 0.6 & 21.0 \\
\hline $\begin{array}{l}\text { Calotropin } \\
\text { procera }\end{array}$ & 73.0 & 6279.6 & $\begin{array}{l}\text { Low } \\
\text { dense }\end{array}$ & 628.0 & Low & 13.6 \\
\hline $\begin{array}{l}\text { Azardirachta } \\
\text { indica }\end{array}$ & 48.8 & 4229.9 & $\begin{array}{l}\text { Low } \\
\text { dense }\end{array}$ & 467.0 & $0.56-0.85$ & 0.68 \\
\hline Acassia & 42.6 & 4695.8 & dense & 735.0 & $0.67-0.68$ & 0.68 \\
\hline
\end{tabular}




\begin{tabular}{|l|l|l|l|l|l|l|}
\hline nilotica & & & & & & \\
\hline $\begin{array}{l}\text { Accasia } \\
\text { senegal }\end{array}$ & 39.4 & 3200.0 & dense & 1338.0 & High & 11.766 \\
\hline Rice hulk & 0.00 & 2943.0 & dense & 2943.0 & $\begin{array}{l}\text { Conditional } \\
\text { In }\end{array}$ & 15 \\
\hline Cowdung & 74.8 & 2052.5 & & 2052.5 & Low too & 27.9 \\
\hline
\end{tabular}

In the table (table1) the eleven fuel types were found to have the following potentials as biofuel:

\subsection{Moisture Content ( $m c$ )}

Calotropis procera and cowdung has the highest percentages moisture content of $75 \%$, followed by Zizypus spina Christis with 58.4\%, and Gmelina 29.6\%, arborea $47.2 \%$ Azadirchta indica 48.8\%, Accacia seyal 42.6\%, Casia siamea 45.4\%, Accacia nilotica 42.6\%, where the least moisture content was obtained from Eucalyptus Camaldulensis $38.6 \%$ and Accasia Senegal $39.4 \%$, rice hulk has $0.00 \%$ moisture content.

The analysis of variance for moisture content (wet weight) for paired means (table 2) were generally significant at $1 \%$. The coefficient of variation within replication was 0.00 to $14 \%$.

The Difference between Paired Mean of Fuel Types Campared to Lsd Value per Moisture Content Wet Wight

\begin{tabular}{|c|c|c|c|c|c|c|c|c|c|c|c|c|c|c|c|c|c|c|c|c|c|c|c|c|c|c|}
\hline $1 \& 2$ & 24.2 & $<39$. & $2 \& 3$ & 212.1 & $>39.4$ & $3 \& 4$ & 154. & $>39$. & $4 \& 5$ & 21.2 & $<39$. & $5 \& 6$ & 30.7 & $<39$. & $6 \& 7$ & 40.0 & $>39$. & $7 \& 8$ & 2.2 & $<39$. & $43.6>39.4$ & $8 \& 9$ & $9 \& 1$ & $0.4<39.4$ & $10 \& 1$ & $591.6>39.4$ \\
\hline $1 \& 3$ & 236.4 & $>39$. & $2 \& 4$ & 366.4 & $>39.5$ & $3 \& 5$ & 175. & $>39$. & $4 \& 6$ & 51.9 & $>39$. & $5 \& 7$ & 70.7 & $>39$. & $6 \& 8$ & 42.2 & $>39$. & $7 \& 9$ & 45.8 & $>39$. & $44.0>39.4$ & $8 \& 1$ & $9 \& 1$ & $592.0>39.4$ & & \\
\hline $1 \& 4$ & 290.7 & $>39$. & $2 \& 5$ & 387.6 & $>39.6$ & $3 \& 6$ & 206 . & $>39$. & $4 \& 7$ & 91.9 & $>39$. & $5 \& 8$ & 72.9 & $>39$. & $6 \& 9$ & 858 & $>39$. & $7 \& 1$ & 46.2 & $>39$. & $635.6>39.4$ & $8 \& 1$ & & & & \\
\hline $1 \& 5$ & 411.9 & $>39$. & $2 \& 6$ & 418.3 & $>39.7$ & $3 \& 7$ & 246. & $>39$. & $4 \& 8$ & 94.1 & $>39$. & $5 \& 9$ & 116. & $>39$. & $6 \& 1$ & 86.8 & $>39$. & $7 \& 1$ & 637. & $>39$. & & & & & & \\
\hline $1 \& 6$ & 442.6 & $>39$. & 287 & 458.3 & $>39.7$ & $3 \& 8$ & 248. & $>39$. & $4 \& 9$ & 137. & $>39$. & $5 \& 1$ & 116. & $>39$. & $6 \& 1$ & 677. & $>39$. & & & & & & & & & \\
\hline $1 \& 7$ & 482.6 & $>39$. & $2 \notin 8$ & 460.5 & $>39.8$ & $3 \& 9$ & 292. & $>39$. & $4 \& 10$ & 138. & $>39$. & $5 \& 1$ & 708. & $>39$. & & & & & & & & & & & & \\
\hline $1 \& 8$ & 484.8 & $>39$. & $2 \& 9$ & 504.1 & $>39.9$ & $3 \& 1$ & 292. & $>39$. & $4 \& 1$ & 729. & $>39$. & & & & & & & & & & & & & & & \\
\hline $1 \& 9$ & 528.4 & $>39$. & $2 \& 14$ & 504.5 & $>39.1$ & $3 \& 1$ & 884. & $>39$. & & & & & & & & & & & & & & & & & & \\
\hline $1 \& 1$ & 528.8 & $>39$. & $2 \& 1$ & 1096 . & $>39.1$ & & & & & & & & & & & & & & & & & & & & & \\
\hline $1 \& 1$ & 1120. & $>39$. & & & & & & & & & & & & & & & & & & & & & & & & \\
\hline
\end{tabular}

$1=$ Cow-dung

$2=$ Calotropis procera

3 = Zizyplus spina Christi

$4=$ Azadirachta indica

$5=$ Gmelina arborea

$6=$ Cassia siamea
$7=$ Acacia seyal

$8=$ Acacia nilotica

$9=$ Eucalyptus camaldulensis

$10=$ Acacia senegal

11 = Rice hull (husk)

The differences between all paired means were significant at $1 \%$ for M.C. wet pory and wood retained. 


\section{Macrothink}

Journal of Environment and Ecology

ISSN 2157-6092

2015, Vol. 6, No. 2

THE DIFFERENCE BETWEEN PAIRED MEAN OF FUEL TYPES COMPARED TO

L.S.D. VALUE FOR MOISTURE CONTENT DRY WEIGHT

\begin{tabular}{|l|l|l|l|l|l|l|l|l|l|l|l|l|l|l|l|l|l|l|l|}
\hline $1 \& 2$ & $22.0>15.3$ & $2 \& 3$ & $130.0>15.3$ & $3 \& 4$ & $49.0>15.3$ & $4 \& 5$ & $5.0>15.3$ & $5 \& 6$ & $70.0>15.3$ & $6 \& 7$ & $8.0>15.3$ & $7 \& 8$ & $1.0>15.3$ & $8 \& 9$ & $8.0>15.3$ & $9 \& 10$ & $1.0>15.3$ & $10 \& 11$ & $65.0>15.3$ \\
\hline $1 \& 3$ & $152.0>15.3$ & $2 \& 4$ & $179.0>15.3$ & $3 \& 5$ & $54.0>15.3$ & $4 \& 6$ & $12.0>15.3$ & $5 \& 7$ & $15.0>15.3$ & $6 \& 8$ & $9.0>15.3$ & $7 \& 9$ & $9.0>15.3$ & $8 \& 10$ & $9.0>15.3$ & $9 \& 11$ & $66.0>15.3$ & & \\
\hline $1 \& 4$ & $201.0>15.3$ & $2 \& 5$ & $184.0>15.3$ & $3 \& 6$ & $61.0>15.3$ & $4 \& 7$ & $20.0>15.3$ & $5 \& 8$ & $16.0>15.3$ & $6 \& 9$ & $17.0>15.3$ & $7 \& 10$ & $10.0>15.3$ & $8 \& 11$ & $74.0>15.3$ & & & \\
\hline $1 \& 5$ & $506.0>15.3$ & $2 \& 6$ & $191.0>15.3$ & $3 \& 7$ & $69.0>15.3$ & $4 \& 8$ & $21.0>15.3$ & $5 \& 9$ & $24.0>15.3$ & $6 \& 10$ & $18.0>15.3$ & $7 \& 11$ & $75.0>15.3$ & & & & \\
\hline $1 \& 6$ & $213.0>15.3$ & $2 \& 7$ & $199.0>15.3$ & $3 \& 8$ & $70.0>15.3$ & $4 \& 9$ & $29.0>15.3$ & $5 \& 10$ & $25.0>15.3$ & $6 \& 11$ & $83.0>15.3$ & & & & & & \\
\hline $1 \& 7$ & $221.0>15.3$ & $2 \& 8$ & $200.0>15.3$ & $3 \& 9$ & $78.0>15.3$ & $4 \& 10$ & $30.0>15.3$ & $5 \& 11$ & $90.0>15.3$ & & & & & & & & \\
\hline $1 \& 8$ & $222.0>15.3$ & $2 \& 9$ & $208.0>15.3$ & $3 \& 10$ & $79.0>15.3$ & $4 \& 11$ & $95.0>15.3$ & & & & & & & & & & \\
\hline $1 \& 9$ & $230.0>15.3$ & $2 \& 10$ & $209.0>15.3$ & $3 \& 11$ & $144.0>15.3$ & & & & & & & & & & & & \\
\hline $1 \& 10$ & $231.0>15.3$ & $2 \& 11$ & $274.0>15.3$ & & & & & & & & & & & & & & \\
\hline $1 \& 11$ & $296.0>15.3$ & & & & & & & & & & & & & & & & \\
\hline
\end{tabular}

$1=$ Cow-dung

$2=$ Calotropis procera

$3=$ Zizyplus spina Christi

$4=$ Azadirachta indica

$5=$ Gmelina arborea

$6=$ Cassia siamea

$$
\begin{aligned}
& 7=\text { Acacia seyal } \\
& 8=\text { Acacia nilotica } \\
& 9 \text { = Eucalyptus camaldulensis } \\
& 10=\text { Acacia senegal } \\
& 11 \text { = Rice hull (husk) }
\end{aligned}
$$

\begin{tabular}{|c|c|c|c|c|c|c|c|c|c|c|c|c|c|c|c|c|c|c|c|}
\hline $1 \& 2$ & $591.6>37.2$ & $2 \& 3$ & $0.4<37.2$ & $3 \& 4$ & $43.8>37.2$ & $4 \& 5$ & $2<>37.2$ & $5 \& 6$ & $40.0>37.2$ & $6 \& 7$ & $30.7>37.2$ & $7 \& 8$ & $21.2>37.2$ & $8 \& 9$ & $154.3>37.2$ & $9 \& 10$ & $236.4>37.2$ & $10 \& 11$ & $65.7>37.2$ \\
\hline $1 \& 3$ & $592.0>37.2$ & $2 \& 4$ & $44.2>37.2$ & $3 \& 5$ & $45.8>37.2$ & $4 \& 6$ & $42.0>37.2$ & $5 \& 7$ & $70.7>37.2$ & $6 \& 8$ & $51.9>37.2$ & $7 \& 9$ & $175.5>37.2$ & $8 \& 10$ & $390.7>37.2$ & $9 \& 11$ & $302.1>37.2$ & & \\
\hline $1 \& 4$ & $635.8>37.2$ & $2 \& 5$ & $46.2>37.2$ & $3 \& 6$ & $85.8>37.2$ & $4 \& 7$ & $72.7>37.2$ & $5 \& 8$ & $91.9>37.2$ & $6 \& 9$ & $206.2>37.2$ & $7 \& 10$ & $411.9>37.2$ & $8 \& 11$ & $456.4>37.2$ & & & & \\
\hline $1 \& 5$ & $637.8>37.2$ & $2 \& 6$ & $86.2>37.2$ & $3 \& 7$ & $116.5>37.2$ & $4 \& 8$ & $93.9>37.2$ & $5 \& 9$ & $246.2>37.2$ & $6 \& 10$ & $442.6>37.2$ & $7 \& 11$ & $477.6>37.2$ & & & & & & \\
\hline $1 \& 6$ & $677.8>37.2$ & $2 \& 7$ & $116.9>37.2$ & $3 \& 8$ & $137.7>37.2$ & $4 \& 9$ & $248.2>37.2$ & $5 \& 10$ & $482.6>37.2$ & $6 \& 11$ & $508.3>37.2$ & & & & & & & & \\
\hline $1 \& 7$ & $708.5>37.2$ & $2 \& 8$ & $1381>37.2$ & $3 \& 9$ & $292.4>37.2$ & $4 \& 10$ & $484.6>37.2$ & $5 \& 11$ & $548.3>37.2$ & & & & & & & & & & \\
\hline $1 \& 8$ & $729.7>37.2$ & $2 \& 9$ & $292.4>37.2$ & $3 \& 10$ & $528.4>37.2$ & $4 \& 11$ & $550.3>37.2$ & & & & & & & & & & & & \\
\hline $1 \& 9$ & $884.0>37.2$ & $2 \& 10$ & $528.8>37.2$ & $3 \& 11$ & $594.1>37.2$ & & & & & & & & & & & & & & \\
\hline $1 \& 10$ & $1120.4>37.2$ & $2 \& 11$ & $594.5>37.2$ & & & & & & & & & & & & & & & & \\
\hline $1 \& 11$ & $1186.1>37.2$ & & & & & & & & & & & & & & & & & & \\
\hline
\end{tabular}

THE DIFFERENCE BETWEEN PAIRED MEAN OF FUEL COMPARED TO L.S.D.

VALUE PER PROPORTION OF WOOD RETAINED

$1=$ Rice hull (husk)

$$
7=\text { Gmelina arborea }
$$

$2=$ Acacia senegal

$$
8=\text { Azadirachta indica }
$$

3 = Eucalyptus camaldulensis $9=$ Zizyplus spina Christi

$4=$ Acacia nilotica $10=$ Cow-dung

$5=$ Acacia seyal $11=$ Calotropis procera 
$6=$ Cassia siamea

\subsection{Caloric Value}

This plant material with the highest caloric value was Caloptropis procera $6279.6 \mathrm{kcal} / \mathrm{kg}$ followed by Cassia siamea and Eucalyptus camadulensis $5883.70 \mathrm{kcal}$ and $5506.9 \mathrm{kcal} / \mathrm{kg}$ respectively. This was followed by Gmelina arborea $(4741.31 \mathrm{kcal} / \mathrm{kg})$, Accasia seyal $4666.1 \mathrm{kcal}$.

Acacia seyal (4666.1) $\mathrm{kcal}$ and Azadirchta indica (4221.9 kcal $/ \mathrm{kg}$ ). Those with the least caloric value were Zizyphus spina christi (3076.6 kcal/kg). Acacia Senegal (3200.0kcal), rice hull $(2943 \mathrm{kcal} / \mathrm{kg})$ and cowdung $(2052.5 \mathrm{kcal} / \mathrm{kg})$.

\subsection{Specific Heat Capacity}

The highest specific heat capacity was obtain from rice hulk (2943.03). Gmehira arborea (2304.0) and cowdung (2052.5) followed by Accacia Senegal (1338.0) Cassia siamea (1122.0) and Zizyphus spina Christi (1011.0) those with the least heat capacity includes Acacia nilotica (735.0) Calotropis procera (628.0) and Eucalyptus Camaldulensis (336.0).

\subsection{Specific Gravity}

Specific gravity was highest among Zizyphus spina Christi (0.93) Cassia siamea (0.6-0.8) and Acasia nilotica (0.67-0.68) and Azadirchta indica (0.56-0.85) while Gmelira arborea has the least specific gravity of $0.42-0.64$.

Rice hull has a high specific gravity on compaction.

\subsection{ASH Content}

Among the eleven fuel materials identified cowdung has the highest percentage ash content of 27.9\%. Ngulde e'tal (2013) 0btain 41.1\% followed by Gmelina arborea 22.7\%, Eucalyptus camaldelia 21.01, Zizyphus spina Christi 21.02 followed by Cassisiama 15.3\%, rice hulk 15\%, Calotropis procera 13.6L and Acacia seyal, others are acacia Senegal $11.76 \%$ Acacia nilotica 10.7, while Azadrachta indica was $0.68 \%$.

THE DIFFERENCE BETWEEN PAIRED MEAN OF FUEL TYPES COMPARED TO L.S.D. VALUE FOR MOISTURE CONTENT DRY WEIGHT

\begin{tabular}{|l|l|l|l|l|l|l|l|l|l|l|l|l|l|l|l|l|l|l|l|}
\hline $1 \& 2$ & $22.0>15.3$ & $2 \& 3$ & $130.0>15.3$ & $3 \& 4$ & $49.0>15.3$ & $4 \& 5$ & $5.0>15.3$ & $5 \& 6$ & $70.0>15.3$ & $6 \& 7$ & $8.0>15.3$ & $7 \& 8$ & $1.0>15.3$ & $8 \& 9$ & $8.0>15.3$ & $9 \& 10$ & $1.0>15.3$ & $10 \& 11$ & $65.0>15.3$ \\
\hline $1 \& 3$ & $152.0>15.3$ & $2 \& 4$ & $179.0>15.3$ & $3 \& 5$ & $54.0>15.3$ & $4 \& 6$ & $12.0>15.3$ & $5 \& 7$ & $15.0>15.3$ & $6 \& 8$ & $9.0>15.3$ & $7 \& 9$ & $9.0>15.3$ & $8 \& 10$ & $9.0>15.3$ & $9 \& 11$ & $66.0>15.3$ & & \\
\hline $1 \& 4$ & $201.0>15.3$ & $2 \& 5$ & $184.0>15.3$ & $3 \& 6$ & $61.0>15.3$ & $4 \& 7$ & $20.0>15.3$ & $5 \& 8$ & $16.0>15.3$ & $6 \& 9$ & $17.0>15.3$ & $7 \& 10$ & $10.0>15.3$ & $8 \& 11$ & $74.0>15.3$ & & \\
\hline $1 \& 5$ & $506.0>15.3$ & $2 \& 6$ & $191.0>15.3$ & $3 \& 7$ & $69.0>15.3$ & $4 \& 8$ & $21.0>15.3$ & $5 \& 9$ & $24.0>15.3$ & $6 \& 10$ & $18.0>15.3$ & $7 \& 11$ & $75.0>15.3$ & & & & \\
\hline $1 \& 6$ & $213.0>15.3$ & $2 \& 7$ & $199.0>15.3$ & $3 \& 8$ & $70.0>15.3$ & $4 \& 9$ & $29.0>15.3$ & $5 \& 10$ & $25.0>15.3$ & $6 \& 11$ & $83.0>15.3$ & & & & & & \\
\hline $1 \& 7$ & $221.0>15.3$ & $2 \& 8$ & $200.0>15.3$ & $3 \& 9$ & $78.0>15.3$ & $4 \& 10$ & $30.0>15.3$ & $5 \& 11$ & $90.0>15.3$ & & & & & & & & \\
\hline $1 \& 8$ & $222.0>15.3$ & $2 \& 9$ & $208.0>15.3$ & $3 \& 10$ & $79.0>15.3$ & $4 \& 11$ & $95.0>15.3$ & & & & & & & & & & \\
\hline $1 \& 9$ & $230.0>15.3$ & $2 \& 10$ & $209.0>15.3$ & $3 \& 11$ & $144.0>15.3$ & & & & & & & & & & & & \\
\hline $1 \& 10$ & $231.0>15.3$ & $2 \& 11$ & $274.0>15.3$ & & & & & & & & & & & & & & \\
\hline $1 \& 11$ & $296.0>15.3$ & & & & & & & & & & & & & & & \\
\hline
\end{tabular}


$1=$ Cow-dung

$2=$ Calotropis procera

3 = Zizyplus spina Christi

4 = Azadirachta indica

$5=$ Gmelina arborea

$6=$ Cassia siamea
$7=$ Acacia seyal

$8=$ Acacia nilotica

$9=$ Eucalyptus camaldulensis

$10=$ Acacia senegal

11 = Rice hull (husk)

\subsection{Fish Types and Percentage Loss in Weight}

The wet and dry weight of fish vary with the species. Eight species of fish were considered for this research namely Lates, Sarotheradon, Galileaa, Hydrocynoea, Forskali, Tilapia zilli, Sarotherodon nilotica, Cithanium citnanus, Distichhdon rostratus, and Clarias. These species of fish were assessed for loss of body weight which could be attributed to dressing and smoking (Table 3). The percentage loss in weight due to dressing were $14.8-21.4 \%$, and $37.95-68.08 \%$ respectively. The total mean weight loss ranged from $52.92 \%$ to $83.83 \%$, which represents $8.27-113.97 \mathrm{~g}$ dressing and 19.83-313.0g smoking. The fish Cithanium cithanus weighing $0.91 \mathrm{~kg}$ recorded the highest weight loss of $68 \%$ due to smoking with only $15.8 \%$ due to dressing weight $0.9 \mathrm{~kg}$ followed by Sarotherodon nilotica with 54.45 and 21.35 for smoking and dressing respectively. Claris $6.5 \mathrm{~kg}$ and fantherodin galilea11.11 kg followed with 52.94 and with 19.24 and 52.84 and with 16.93 due to dressing and smoking respectively.

Lates has a weight of $2.61 \mathrm{~kg}$ has the least weight loss due to smoking $37.45 \%$ and $15.01 \%$ due to dressing (Table 3) weight $2.61 \mathrm{~kg}$.

The amount of heat required to dry or smoke species of fish was recorded from Citharium cithanus with $380.34 \mathrm{kcal}$ being the highest heat consumption, followed by Sarotherodon nilotica and sarotherodon galileae $293.50 \mathrm{kcal}$ and $284.8 \mathrm{kcal}$ respectively. Clarias and Tilapia consmeal aborea 2277.6 and 274.57 respectively. The least consumption and heat came from Lates (240.55). From the finding recorded this research, fish processor around the Lake Chad gives priority to dried wood in addition to hardy, strong, heavy dense, good charcoal, less smoke and intensive heat. Among all the fuel types mentioned or assessed in this study, Acasia nilotica has all the desired attributes but it is not woody and scarce. In addition to the desired attributes Acacia seyal was preferred secure the smoke is pleasant and used as a perfume by women, however it sputter. Some of the fuel types were identified with some undersirable attributes for example Gmelina arborea is pulpy and not heavy, Cassia siamea is toxic and smoky with soot, Eucalyptus camaldulensis is not dense, smokes heavily and burnt faster than Acacia nilotica and it has an allilophathic effect to other trees, so it is not encouraged for growth in the vicinity of other fuel types.

Calotroris procera is poor in all attributes despite its high caloric value. Azadirachta indica in not hard but granular and produces poor charcoal and allelopathic to crops but a good insect repellant. Acacia nilotica despite its preference it contains some gum and the smoke is choky 
which can be carcinogenic which is no known to the processors and fish consumers. As one of the wastes material identified as fuel, cow dung is not socially good and its use was kept confidential among processors. This is due to the dungs acrid smell and may affect the quality and market value of the product if known to consumers. Acacia Senegal was not commonly used but good in all attributes, may be due to its good qualities as a biofuel which led to its over extraction from source. Secondly it is controlled because it is cultivated for its various grades of gum and not readily wet for fuel. Considering all the fuel types and their attributes moisture content of wood or fuel type is a major factor in the efficiency of a fuelwood, a wood with low moisture content less energy is required to evaporate the moisture before heating the cooking surfaces. The National Academy of Science (1980) indicated drying of wood to moisture content of 20 to $25 \%$ will reduce the quantity of wood needed for a given heating requirement by $20 \%$ or more.

In the study the least moisture content indicated rice hull are good source of bioenergy where they are available and no prior processing is required before burning. Mendoga and Samson (2006), indicated that 1.5 tones of rice husk was burnt as biofuel was observed as a good fuel in Eucalyptus camaldulens is $38 \%$ while rice hull recorded $0.00 \%$, both fuel types were accessible to fish processors. The available and accessible types were Calotropis (73\% m.c) and cowdung (74.8\%m.c). Calotropis procera is common and contain some poisonous sap and such poisonous materials which are poisonous deteriorate at high temperature or under stressful condition and evaporate in the air.

The same constituents were found in cow dung being an animal wastes containing nitrogenous volatile substances. Volatile substances like phenol, cation and materials which escape into the air in a certain temperature $\left(43^{\circ} \mathrm{c}\right)$ were commonly associated with calotropis species and cowdung. The dispersal particles commonly being to the hydrocarbon family or terpenes which includes substances as essential oils balsam, resins, comphor carotenoids and rubber. Among these substances particularly the whitish sap found in calotropis contains protein ,alkaloids, vitamins hydrycarbons of terpens oil, balsam resins campor rubber B, oxalates and mates as indicated by (Esau, 1965). Most of these substances are found in smoked fish as reported by (Eyo, 1980), however they are carcinogenic and some impact some unpleasant flavor to the fish.

Calotropis procera and cow dung had the highest moisture content of $75 \%$. This type of fuel materials cannot be efficient in fish processing. A lot of the calories are required to smoke and dry the fish is diverted in evaporating the moisture content. Calotropis with caloric value at $6279.6 \mathrm{kcal} / \mathrm{kg}$ with $73 \mathrm{Lm}$.c will divert $5090.8 \mathrm{kcal} / \mathrm{kg}$ or wood evaporate the moisture content before heating this fish substances while cow dung with a caloric value of 2052.5 $\mathrm{kcal} / \mathrm{kg}$ and a moisture content at $75 \%$ will divert about $603.9 \mathrm{kcal} / \mathrm{kg}$ of the wastes before heating the fish surface. This compared Eucalyptus camadulensis as fuel with a caloric value of $5506.9 \mathrm{kcal} / \mathrm{kg}$ and a moisture content of $39.0 \%$ which will divert about $319.0 \mathrm{kcalkg}$ of wood, similarly Acacia Senegal has a caloric value of $3200 \mathrm{kcal} / \mathrm{kg}$ with a moisture content of 378 will require about $319 \mathrm{kcal} / \mathrm{kg}$ of wood to evaporate moisture before heating the fish surface while it is being smoked. So Eucalyptus camaldulensis and Acacia Senegal could be selected as the best fuel types around the Lake Chad despite their scarcity and cost but they 
are promising in moisture content as the most important factor affecting the quality of fuel wood.

FISH TYPES, NUMBER, WEIGHT AND PERCENTAGE LOSS IN WEIGHT

\begin{tabular}{|c|c|c|c|c|c|c|c|c|c|c|c|}
\hline S.No. & $\begin{array}{l}\text { Specie Name } \\
\text { (Fish) }\end{array}$ & $\begin{array}{l}\text { Number } \\
\text { of } \\
\text { Sample }\end{array}$ & $\begin{array}{l}\text { Total } \\
\text { Weight } \\
\text { (g) }\end{array}$ & $\begin{array}{l}\text { Mean } \\
\text { Weight } \\
\text { 'g' }\end{array}$ & $\begin{array}{l}\text { Final } \\
\text { Mean } \\
\text { Weight } \\
\text { Loss 'g' }\end{array}$ & $\begin{array}{l}\text { Mean Weight } \\
\text { Loss from } \\
\text { Dressing \% }\end{array}$ & $\begin{array}{l}\text { Mean Weight } \\
\text { Loss from } \\
\text { Smoking \% }\end{array}$ & $\begin{array}{l}\text { Mean } \\
\text { Total } \\
\text { Loss in } \\
\text { Weight } \\
\text { 'g' }\end{array}$ & $\begin{array}{l}\text { Mean } \\
\text { Quality of } \\
\text { Weight } \\
\text { Loss } \\
\text { Smoking } \\
\text { 'g' }\end{array}$ & $\begin{array}{l}\text { Mean } \\
\text { Quantity } \\
\text { of Weight } \\
\text { Loss from } \\
\text { Dressing }\end{array}$ & $\begin{array}{l}\text { Quantity of } \\
\text { Heat (Kcal) } \\
\text { required to } \\
\text { Evaporate } \\
\text { Water Kcal } \\
\mathrm{kg} \text { fish }\end{array}$ \\
\hline 1. & $\begin{array}{l}\text { Lates } \\
\text { Giwan ruwa }\end{array}$ & 4 & 2635.18 & $658.80 \mathrm{~g}$ & $348.63 \mathrm{~g}$ & $15.01 \%$ & $37.45 \%$ & $52.92 \%$ & $250.10 \mathrm{~g}$ & $98.89 \mathrm{~g}$ & 204.55 \\
\hline 2. & $\begin{array}{l}\text { Sarotherodon } \\
\text { Galileaea }\end{array}$ & 20 & 11846.9 & $592.35 \mathrm{~g}$ & $426.97 \mathrm{~g}$ & $19.24 \%$ & $52.84 \%$ & $72.08 \%$ & $313.00 \mathrm{~g}$ & $113.97 \mathrm{~g}$ & 284.81 \\
\hline 3. & $\begin{array}{l}\text { Hydrocynon } \\
\text { Forskali }\end{array}$ & 12 & 1210.0 & $100.8 \mathrm{~g}$ & $58.25 \mathrm{~g}$ & $14.80 \%$ & $43.18 \%$ & $57.78 \%$ & $43.54 \mathrm{~g}$ & $14.92 \mathrm{~g}$ & 232.75 \\
\hline 4. & $\begin{array}{l}\text { Tilapia zilli } \\
\text { Karfasa }\end{array}$ & 13 & 1106.10 & 85.08 & $58.96 \mathrm{~g}$ & 18.36 & 50.94 & 69.30 & 43.34 & 15.62 & 274.57 \\
\hline 5. & $\begin{array}{l}\text { Sarotherodon } \\
\text { Nilotica }\end{array}$ & 9 & 743.75 & 82.64 & 62.64 & 21.35 & 54.45 & 75.88 & 45.00 & 17.64 & 293.50 \\
\hline 6. & $\begin{array}{l}\text { Cithanium } \\
\text { cithanius } \\
\text { H-fallya }\end{array}$ & 15 & 927.50 & 61.83 & 51.83 & 15.83 & 68.00 & 83.83 & 43.82 & 08.27 & 380.34 \\
\hline 7. & $\begin{array}{l}\text { Distichodon } \\
\text { rostratus } \\
\text { Chi-chiyawa }\end{array}$ & 15 & 1337.50 & 89.17 & 55.42 & 17.30 & 45.02 & 62.15 & 40.14 & 15.43 & 242.63 \\
\hline 8. & $\begin{array}{l}\text { Clarias A } \\
\text { Tarwada }\end{array}$ & 23 & 2000.0 & 86.96 & 70.00 & 16.26 & 64.24 & 80.50 & 55.86 & 14.14 & 346.23 \\
\hline 9. & $\begin{array}{l}\text { Clarias B } \\
\text { Tarwada }\end{array}$ & 25 & 2000.0 & 80.00 & 66.00 & 15.12 & 67.38 & 82.50 & 49.34 & 12.10 & 332.43 \\
\hline 10. & $\begin{array}{l}\text { Clarias C } \\
\text { Tarwada }\end{array}$ & 20 & 1010.0 & 50.50 & 28.46 & 17.10 & 39.26 & 56.36 & 19.83 & 8.64 & 211.65 \\
\hline 11. & $\begin{array}{l}\text { Clarias D } \\
\text { Tarwada }\end{array}$ & 20 & 1530.00 & 76.50 & 46.00 & 19.24 & 40.89 & 60.13 & 31.28 & 14.72 & 220.39 \\
\hline
\end{tabular}

\subsection{Fish Processing}

Processing of fish around the Lake Chad was tedious and expensive due to lack of domestic fuel. In response to this fish farmers prefer to sell their fish fresh coupled with the additional labour in collecting and buying the scarce and expensive wood. Other problems involves dressing of fish on tying the fish head to tail especially Clarias and this was less vigorous than smoking the fish.

Eyo (1983) reported on inevitable loss in body weight packing dressing and smoking affect 
the market price and their accounts for about $50.80 \%$ of the fresh weight. Generally he noted that the smoking at high resulting in some loss of vitamins like thiamin (2-25) with negligible loss in mass and riboflavin. Lysine is nutritionally the most important amino acid in fish and it was liable to heat reaction (browning of fish). So the proportionate loss in body weight of the Nitrous species could not be due to moisture alone but some vitamins and proteins. Eyo (1980) Observed that lysine content (vitamins) of the surface layer fell progressive3ly to $75 \%$ of its original value over fine losses of smoking pawl to some $89 \%$ in the underneath. Lost of fresh value can be avoided by reducing the time or exposure to heat or the time of exposure should be specifically for moisture loss (surface moisture).

Singh (2014) reported that traditionally smoking a combination or drying and adding chemicals from the smoke to the fish thus preserving and adding flavors to the final products. However much of the smoked fish for the day is exposed to smoke for long enough to provide the desired flavor with little if any drying.

The smoking process also required soaking butchered fish in a $70-80 \%$ brine solution for a few hours to overnight.

QUANTITY OF HEAT J/KG REQUIRED TO RAISE THE TEMP OF WATER/KG/SPECIE OF FUEL TYPES

\begin{tabular}{|c|c|c|c|c|c|c|c|c|c|c|c|c|c|c|}
\hline S.No. & $\begin{array}{l}\text { Specie Name } \\
\text { (Fish) }\end{array}$ & $\begin{array}{l}\text { Quantity } \\
\text { of } \\
\text { Water } / \mathrm{kg} \\
\text { of Fish }\end{array}$ & $\begin{array}{l}\text { Quantity } \\
\text { of Heat } \\
\text { Required } \\
\text { to } \\
\text { Evaporate } \\
\text { Water } \\
\text { (Kcal kg) }\end{array}$ & $\begin{array}{l}\text { A1 } \\
1.01 \mathrm{j} / \mathrm{g}\end{array}$ & $\begin{array}{l}\mathrm{A} 2 \\
2.30 \mathrm{j} / \mathrm{g}\end{array}$ & $\begin{array}{l}\text { A3 } \\
1.12 \mathrm{j} / \mathrm{g}\end{array}$ & $\begin{array}{l}\text { A4 } \\
1.13 \mathrm{j} / \mathrm{g}\end{array}$ & $\begin{array}{l}\text { A5 } \\
0.34 \mathrm{j} / \mathrm{g}\end{array}$ & $\begin{array}{l}\text { A6 } \\
0.63 / \mathrm{jg}\end{array}$ & $\begin{array}{l}\text { A7 } \\
0.4 \mathrm{j} / \mathrm{g}\end{array}$ & $\begin{array}{l}\text { A8 } \\
0.74 \mathrm{j} / \mathrm{g}\end{array}$ & $\begin{array}{l}\text { A9 } \\
2.94 \mathrm{j} / \mathrm{g}\end{array}$ & $\begin{array}{l}\mathrm{A} 10 \\
.05 \mathrm{j} / \mathrm{g}\end{array}$ & $\begin{array}{l}\text { A11 } \\
1.34 \mathrm{j} / \mathrm{g}\end{array}$ \\
\hline 1. & $\begin{array}{l}\text { Lates } \\
\text { Giwan ruwa }\end{array}$ & 379.49 & 204.55 & 383.28 & 872.83 & 425.03 & 428.82 & 129.03 & 239.08 & 178.36 & 280.82 & 1115.70 & 777.95 & 508.52 \\
\hline 2. & $\begin{array}{l}\text { Sarotherodon } \\
\text { Galileaea }\end{array}$ & 528.40 & 284.81 & 533.68 & 1215.32 & 591.81 & 597.09 & 179.66 & 332.89 & 248.35 & 391.02 & 1533.50 & 1083.22 & 708.06 \\
\hline 3. & $\begin{array}{l}\text { Hydrocynon } \\
\text { Forskali }\end{array}$ & 431.82 & 232.75 & 436.14 & 993.19 & 483.64 & 487.96 & 146.82 & 272.05 & 202.96 & 319.55 & 1269.55 & 885.23 & 578.64 \\
\hline 4. & $\begin{array}{l}\text { Tilapia zilli } \\
\text { Karfasa }\end{array}$ & 509.40 & 274.57 & 514.49 & 1171.62 & 570.53 & 575.62 & 173.20 & 320.92 & 239.42 & 376.96 & 1497.64 & 1044.27 & 682.60 \\
\hline 5. & $\begin{array}{l}\text { Sarotherodon } \\
\text { Nilotica }\end{array}$ & 544.53 & 293.50 & 549.98 & 1252.42 & 609.87 & 615.32 & 185.14 & 343.05 & 255.93 & 402.95 & 1600.92 & 1116.29 & 729.67 \\
\hline 6. & $\begin{array}{l}\text { Cithanium } \\
\text { cithanius } \\
\text { H-fallya }\end{array}$ & 705.64 & 380.34 & 712.70 & 1622.97 & 790.32 & 797.37 & 239.92 & 444.55 & 331.65 & 522.17 & 2074.58 & 1446.56 & 945.56 \\
\hline 7. & $\begin{array}{l}\text { Distichodon } \\
\text { rostratus } \\
\text { Chi-chiyawa }\end{array}$ & 450.15 & 242.63 & 454.65 & 1035.35 & 504.17 & 508.67 & 153.05 & 283.59 & 211.57 & 333.11 & 1323.44 & 922.81 & 603.20 \\
\hline 8. & Clarias A & 642.36 & 346.22 & 648.78 & 1477.43 & 719.44 & 725.89 & 218.40 & 404.69 & 301.91 & 475.35 & 1888.54 & 1316.84 & 860.76 \\
\hline
\end{tabular}




\begin{tabular}{|c|c|c|c|c|c|c|c|c|c|c|c|c|c|c|}
\hline & Tarwada & & & & & & & & & & & & & \\
\hline 9. & $\begin{array}{l}\text { Clarias B } \\
\text { Tarwada }\end{array}$ & 616.97 & 332.43 & 622.46 & 1418.62 & 690.80 & 696.97 & 209.71 & 388.58 & 289.89 & 456.42 & 1813.36 & 1264.24 & 826.50 \\
\hline 10. & $\begin{array}{l}\text { Clarias C } \\
\text { Tarwada }\end{array}$ & 392.67 & 211.65 & 396.60 & 903.14 & 439.79 & 443.72 & 133.51 & 247.38 & 184.55 & 290.58 & 1154.45 & 804.97 & 526.18 \\
\hline 11. & $\begin{array}{l}\text { Clarias D } \\
\text { Tarwada }\end{array}$ & 408.89 & 220.39 & 412.98 & 940.45 & 457.96 & 462.05 & 139.02 & 257.60 & 192.18 & 302.58 & 1202.14 & 838.22 & 5471.91 \\
\hline
\end{tabular}

\section{Conclusion}

In conclusion when selecting fuel wood or waste materials as source of fuel for fish smoking respectively in rural areas and places like the lake chad in addition to brining and dressing the type of wood to be utilized are Eucalyptus Camaldulensis and Accasia senegal as the most economical particularly in bulky fish like Clarias. In addition to the above measure a suitable kiln (endorsed) should be used in order to trap the heat for maximum drying and prevention of breeding ground for insects especially the Dermestes beettle which was identified by Azeza. (1983) and Maimbe (1982) identified the Dermetes beetle as responsible for $30 \%$ of spoilage.

\section{Acknowledgement}

We are grateful to the Portsmouth University and the Lead Researcher .Dr, Arthur Neiland for their moral and financial support.

We are also grateful to the Department of Biological Sciences for the facilities used in carrying out this research. We also thank the fish farmers association around the Lake Chad shore for their immense contribution in providing rich information's which added weight to this researchs.

\section{References}

Azeza, N. I. (1977a). Fish processing Technology and production. Annual Report of the Lake Chad Research Institute Maiduguri, 197(80), 35-37.

Azeza, N. I. (1982). Quality assessment in processed fish from Lake Chad destined For Nigeria southern market. Proceedings of the expert consultation on fish technology in Africa, Casablanca, Moroco, $7^{\text {th }}$ June, 1982 FAO fish report no 268(supply), pp.75-83 En.

Azeza, N. I. (1983). Incidence of the use of chemicals Applied as Technique for pro-Tecting Lake Chad processed fish against insect infestation. Annual report of Lake Chad research Institute Maiduguri, Nigeria, 66-67.

Azeza, N. I. (1986). The problem of choice of safer methods of reducing post Harvest losses in Lake Chad processed fish. In fish processing in Africa, proceeding of the FAO expert consultation on fish technology in Africa, Lusaka Zambia 21-25 Jan 1985, FAO (Rome) Pp340-349.FAO, fish report no 329 (suppl) 247p En ref.

Bamako, Mali 13-20. Nov. 1974 CIFA ocass pop. no 4:271-282 fr. FAO (2012); Artisinal fisheries of the Lake Basin in Africa : an overview of information and research. http. 
FAO.Org/docrep/005/u79E/U.

Davis, R. M., \& Davis, O. H. (2009). Traditional and Improved fish processing technologies in Bayelsa state, Nigeria. European Journal of scientific research, 26(4), 539-548.

Durand, J. R. (1980). Evolution of total catch (1962-1977) and the future of fisheries in the Lake Chad region cah. Orstom's. (Hydrobiology), 13(1-2) 93-111, Fr 13 ref.

Eyo, A. A. (1980). The effect of smokes component on the quality and shelf life of Fish.

FAO (1975). A Brief review of the status of the Inland fisheries of the sahelian Zone. FAO (Rome). Fisheries, Dept. Report of consultations on fisheries.

Hopson, A. J. (1968). The gill-net fisheries of Lake Chad. Federal fisheries -service Maiduguri, Nigeria 64p En.

Hopson, A. J. (1972b). A study of the Nile perch (Lates niloticus L.) (Pisces centropo Midea) in Lake Chad .Oversea Research publication 19 HMSO (London 93p.En 81 ref).

Hopson, A. J. (1967a). B1 fish population studies, and B2 Gear Trials. Annual Report, 1966-67. Federal fisheries sources, Lake Chad Research station Mallamfatori. Borno state. Nigeria pp 7-8.

Marie Therese Sarch (1992). Traditional management of Artisinal fisheries, Northern .Nigeria, working papers investigating fisheries Management system Nov, 4-7.

Mendoza I. C., \& Samson (2006). Relative Bioenergy potentials of major Agricultural crop residues in the Philippines. Journal of crop science (PJCS) April, 2006, 31(1) pp11-28. National Academy of Science (NAS) (1980).

National Academy of Science (1980). Non -timber uses of selected Arid zone trees and shrubs in Africa. [Online] Available: http//book.google.com.ng.books.

Neiland, A. E., \& Verinumbe, I. (1990a). Fisheries Development and Resources usage conflict.

Neiland, A. E., \& Verinumbe, I. (1990a). Fisheries Development and resources usage conflict: A case study of Deforestration Development and resources usage conflict.

Neiland, A. E., \& Verinumbe, I. (1990b). The potential of the shrub calotropis Procera (Asclepiadacea) as on Alternative Fuel source for processing fish at Lake Chad in Nigeria. Preliminary observation and identification of areas for further research Trop. Sc. 30, 321-323 en. 6. ref.

Portteous, J. (1978). Structured Timber. Design to Eurocodes.

Nulde, Y. M., \& Yerima, I. Improvement of the thermal Efficiency of Biogas produced form Neem litter. Journal of Biological Sciences and Bioconservation centre for research and innovations, Babaya plaza, western bypass, Niger state, Nigeria. 


\section{Copyright Disclaimer}

Copyright for this article is retained by the author(s), with first publication rights granted to the journal.

This is an open-access article distributed under the terms and conditions of the Creative Commons Attribution license (http://creativecommons.org/licenses/by/3.0/). 